\title{
Xenon and krypton isotope anomalies in the Besner Mine, Ontario, thucholite
}

\author{
P. K. Kuroda and R. D. Sherrill* \\ Department of Chemistry, University of Arkansas, \\ Fayetteville, Arkansas 72701 U.S.A.
}

(Received December 11, 1976)

\begin{abstract}
The isotopic compositions have been measured mass spectrometrically for xenon and krypton fractions released from a sample of thucholite from Besner Mine, Parry Sound, Ontario, Canada, in stepwise heating experiments. The relative abundances of the fissiogenic xenon and krypton isotopes released from the thucholite indicated that they are primarily the product of ${ }^{238} \mathrm{U}$ spontaneous fission. A xenon fraction with an isotopic composition resembling that of the AVCC xenon was released at $400^{\circ} \mathrm{C}$. In the case of krypton, the isotopic composition of a very large fraction of the total gas released at $250^{\circ} \mathrm{C}$ was closer to the AVCC krypton than to the atmospheric krypton. Small excesses of cosmic-ray-produced ${ }^{124} \mathrm{Xe}$ and ${ }^{126} \mathrm{Xe}$ appeared to be present in xenon fractions released at higher temperatures. A possible connection between the occurrence of a meteoritic rare gas component in terrestrial materials and the process of meteorite impact is discussed.
\end{abstract}

\section{INTRODUCTION}

The 'mineral' thucholite is a radioactive hydrocarbon assemblage containing variable amounts of uranium and thorium. Aside from the radioactive elements, it contains carbon, hydrogen, oxygen (hence the name Th-U-C-H$\mathrm{O}$-lite) and unusually high concentrations of rare gases (BoGARD et al., 1965). It is interesting to recall that more than a quarter of a century ago, ORR $(1949,1950)$ put forward the hypothesis that a critical uranium chain reaction might have taken place in thucholite, if its mass was sufficiently great, the carbon contained in the mineral acting as a moderator of neutrons. He studied the ${ }^{235} U$ content of thucholite from the Besner mine, Ontario, for vestiges of 'fossil' reactors. The ${ }^{235} \mathrm{U} /{ }^{238} \mathrm{U}$ ratio in thucholite, however, turned out to be the same as that in normal uranium within 6 percent. Several years later KURODA (1956a, b) evaluated the values of the infinite multiplication constant $\left(\mathrm{k}_{\infty}\right)$ for uranium ore deposits considered as assemblages of fuel $\left({ }^{235} \mathrm{U}\right)$, moderator $\left(\mathrm{H}_{2} \mathrm{O}\right)$ and neutronabsorbing "poisonous" impurities. The results from his calculations indicated that a critical uranium chain reaction could have occurred in pitchblende some 2 billion years ago. The first such case was discovered 16 years later in Gabon, Africa, by a group of French investigators and is now known as the Oklo Phenomenon (Neuilly et al., 1972; see also Kuroda, 1975).

While it was not stated in the report of BogARD et al. (1965), the motive behind their 1965 study on the Besner mine thucholite was to see if the mineral contained a significant excess of ${ }^{235} \mathrm{U}$ fission xenon. Bogard et al. (1965) found that the heavy xenon isotopes ${ }^{131} \mathrm{Xe},{ }^{132} \mathrm{Xe},{ }^{134} \mathrm{Xe}$ and ${ }^{136} \mathrm{Xe}$ were enriched in 3 out of 5 samples of thucholite, but the observed relative abundances of these isotopes indicated that they were primarily the product of ${ }^{238} \mathrm{U}$ spontaneous fission. While they were unable to find vestiges of 'fossil' reactors in thucholite, they made a significant observation that the heavy xenon isotopes were depleted in 2 out of 5 thucholite samples, which presumably had low uranium contents. The ${ }^{136} \mathrm{Xe} /{ }^{130} \mathrm{Xe}$ ratios for these samples were thus intermediate between the values for the atmospheric xenon (2.17) and the average carbonaceous chondrite xenon (1.99). Thus it appeared as if these thucholite samples contained 'common' rare gases, which perhaps represented a very old atmosphere.

The fact that thucholite seemed to contain

* Present Address: Babcock and Wilcox, Lynchburg Research Center, P.O. Box 1260, Lynchburg, Virginia 24505 U.S.A. 
a meteoritic rare gas component has remained as a mystery for nearly a dozen years. Since BOGARD et al. (1965) have measured only the isotopic compositions of the rare gases released from the bulk thucholite samples in total-melting experiments, however, it was felt to be worthwhile to perform a more detailed study on the rare gases released in stepwise heating experiments. The results from such a study carried out for xenon and krypton are presented in this report.

\section{EXPERIMENTAL}

The experimental procedure was essentially the same as that described by KURODA et al. $(1074,1975)$ in their studies on rare gases in the carbonaceous chondrites. A 1.103-gram sample of thucholite from Besner Mine, Parry Sound, Ontario, was analyzed in a stepwise heating experiment employing a Reynolds-type 60 degree mass-spectrometer with a 11.4 centimeter radius of curvature. After preheating at $100^{\circ} \mathrm{C}$ for 12 hours, the sample was placed in a molybdenum crucible and heated with a radiofrequency induction generator for one hour at each extraction temperature. The evolved gases were cleaned in the extraction system by coppercopper oxide at $500^{\circ} \mathrm{C}$ and by titanium at $850^{\circ} \mathrm{C}$. After a secondary scrub on titanium, the rare gases were analyzed after separation by selective adsorption and desorption on charcoal. Neon was separated by adsorption of argon, krypton and xenon at liquid air temperature. Argon was removed when the temperature was raised to that of dry-ice-ethanol; krypton at the freezing point of mercury; and xenon at $300^{\circ} \mathrm{C}$. Average mass discrimination corrections across the krypton and xenon isotopes were about 0.7 and 0.5 percent per mass unit, respectively. In general, the values reported were determined from ten mass peak measurements, with the stated errors representing one standard deviation from the average ratio.

\section{RESUlts AND Discussion}

Tables 1 and 2 show the xenon and krypton isotope data, respectively. A very large fraction of the total gas was released in each case, when the sample was heated to $250^{\circ} \mathrm{C}$. While the isotopic composition of xenon released at $250^{\circ} \mathrm{C}$ was similar to that of the atmospheric xenon, a fairly large quantity of xenon with an isotopic composition resembling that of the AVCC xenon was released at $400^{\circ} \mathrm{C}$. In the case of krypton, the isotopic composition of a very large fraction of the total gas released at $250^{\circ} \mathrm{C}$ was closer to the AVCC krypton than to the atmospheric krypton. Fissiogenic xenon and krypton isotopes were markedly enriched in small volumes of the gases released at higher temperatures, except for the krypton fraction released at $1,800^{\circ} \mathrm{C}$, in which the lighter isotopes were systematically enriched relative to the heavier isotopes.

Figure 1 shows a plot of ${ }^{134} \mathrm{Xe} /{ }^{132} \mathrm{Xe}$ versus ${ }^{136} \mathrm{Xe} /{ }^{132} \mathrm{Xe}$. Note that not only the isotopic ratios for the xenon released from the thucholite sample, but also those for the xenon remaining in the mineral at various temperatures are plotted here. The line $A a$ in Fig. 1 represents a mixing line between the atmospheric xenon $(A)$ and the isotopic composition of the fissiogenic xenon from spontaneous fission of ${ }^{238} \mathrm{U}$. Similarly, the line $A b$ in Fig. 1 represents a mixing line between the atmospheric xenon $(A)$ and the fissiogenic xenon from neutroninduced fission of ${ }^{235} \mathrm{U}$. The line $\mathrm{Am}$ in Fig. 1, on the other hand, shows the variation of the isotopic composition of the atmospheric xenon $(A)$ by mass-dependent fractionation. Most of the data points fall on the line $A a$ in Fig. 1, thus indicating that the thucholite sample contains a fission xenon component, which was produced almost exclusively by spontaneous fission of ${ }^{238} \mathrm{U}$.

Figure 2 shows a plot of ${ }^{131} \mathrm{Xe} /{ }^{132} \mathrm{Xe}$ versus ${ }^{136} \mathrm{Xe} /{ }^{132} \mathrm{Xe}$. The notation in Fig. 2 is the same as that used in Fig. 1. The data points for many of the xenon fractions deviate slightly from the line $A a$ in Fig. 2, toward the line $A b$, representing a mixing line between the atmospheric xenon $(A)$ and the fissiogenic xenon from neutron-induced fission of ${ }^{235} \mathrm{U}$. It thus appears as if the contribution from neutroninduced fission of ${ }^{235} \mathrm{U}$ may amount to a few percent. However, the isotopic composition of the xenon remaining in the bulk mineral at $250^{\circ} \mathrm{C}$ deviates upward from the line $A a$. It is also noteworthy that the data point for the xenon fraction released at $400^{\circ} \mathrm{C}$ lies intermediate between the atmospheric xenon $(A)$ and the AVCC xenon ( $V)$, such as found in the carbonaceous chondrite Murray (K URODA et al., 1974). As shown in Table 1, the amount of xenon released at $250^{\circ} \mathrm{C}$ is about 84 percent of the total and its isotopic composition is essentially that of the atmospheric xenon. The amount of xenon released at $400^{\circ} \mathrm{C}$ is about 


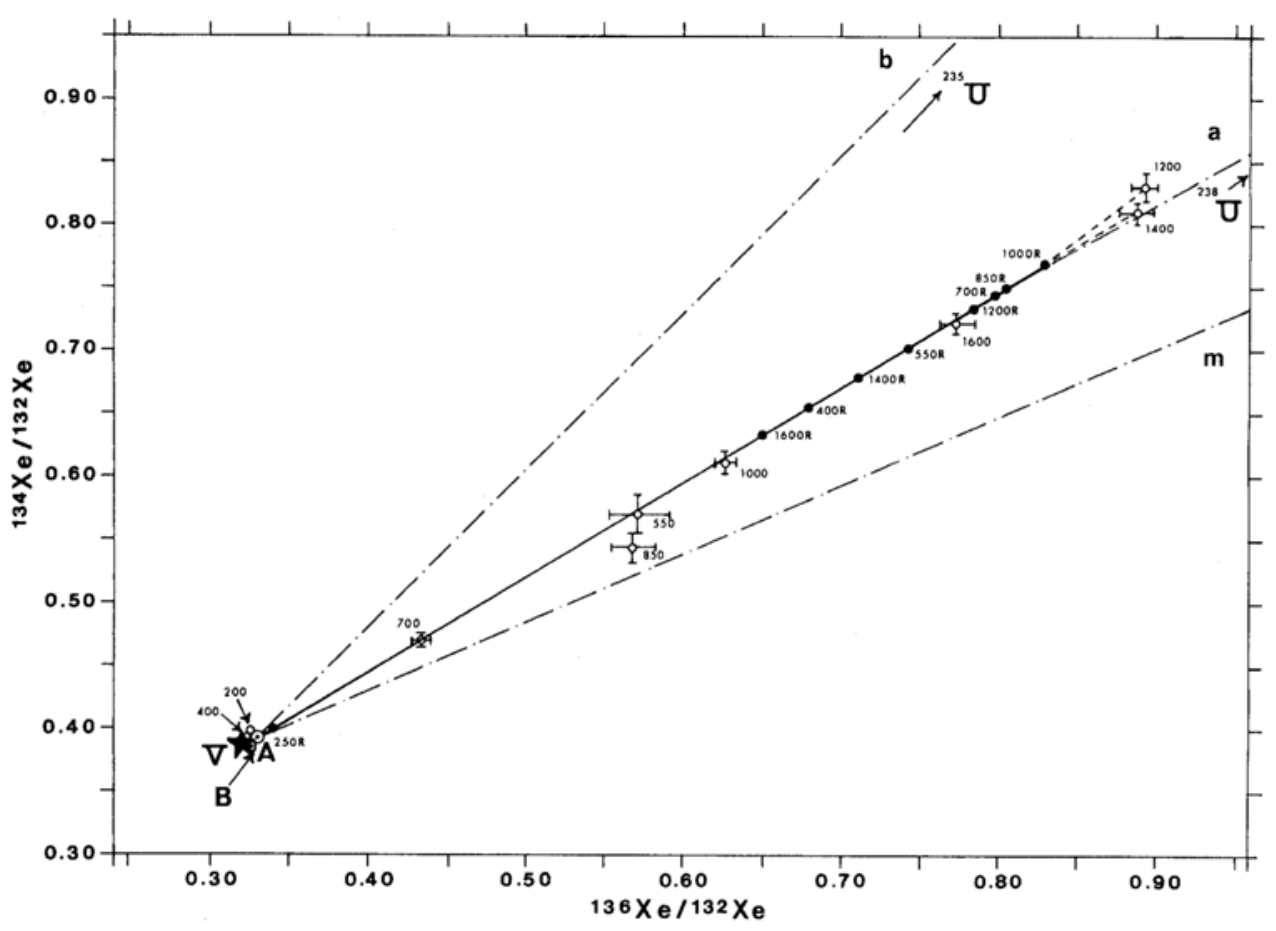

Fig. 1. Plot of ${ }^{134} \mathrm{Xe} /{ }^{132} \mathrm{Xe}$ vs. ${ }^{136} \mathrm{Xe} /{ }^{132} \mathrm{Xe}$ for the xenon fractions released from thucholite.

$\star$ : $A V C C$ Xenon $(V)$

○ : Atmospheric Xenon (A)

$\diamond:$ Xenon in the bulk sample of thucholite $(B)$

$A a$ : Mixing line between the atmospheric xenon $(A)$ and the isotopic composition of the ${ }^{238} U$ spontaneous fission xenon.

$A b$ : Mixing line between the atmospheric xenon $(A)$ and the isotopic composition of the ${ }^{235} U$ fission xenon.

Am : Variation of the isotopic composition of the atmospheric xenon (A) by mass-dependent fractionation.

$\circ$ : Isotopic composition of the xenon released from thucholite at a certain temperature. The release temperature is given near the data point.

- : Isotopic composition of the xenon still remaining in the thucholite at a certain temperature. (The letter $R$ is attached to the release temperature).

15.5 percent of the total and it is far greater than the combined volume of all the xenon fractions released at temperatures above $400^{\circ} \mathrm{C}$, which amounts to less than 1 percent of the total xenon.

Figure 3 shows a plot of ${ }^{130} \mathrm{Xe} /{ }^{132} \mathrm{Xe}$ versus ${ }^{136} \mathrm{Xe} /{ }^{132} \mathrm{Xe}$. The notation in Fig. 3 is the same as that used in previous figures. While most of the data points lie on the line $A a$ in Fig. 3, the data point for the xenon released at $400^{\circ} \mathrm{C}$ falls very close to the isotopic composition $(V)$ for the AVCC xenon. The isotopic composition of the xenon remaining in the bulk mineral at $250^{\circ} \mathrm{C}$ lies closer to $V$ than the atmospheric xenon $(A)$. These results suggest that the thucholite contains a trapped xenon component, which is similar to the AVCC xenon, and this trapped xenon appears to be held by the mineral lattices somewhat more tightly than the atmospheric xenon, which is released at $250^{\circ} \mathrm{C}$. Similar trends are found when the ${ }^{129} \mathrm{Xe} /{ }^{132} \mathrm{Xe}$ and ${ }^{128} \mathrm{Xe} /{ }^{132} \mathrm{Xe}$ ratios are plotted against the ${ }^{136} \mathrm{Xe} /{ }^{132} \mathrm{Xe}$ ratios, although these plots are not shown here.

Figure 4 shows a plot of ${ }^{124} \mathrm{Xe} /{ }^{132} \mathrm{Xe}$ versus ${ }^{136} \mathrm{Xe} /{ }^{132} \mathrm{Xe}$. It is noteworthy that a few data points show marked upward deviations from the line $A a$, suggesting the possibility that small amounts of cosmic-ray-produced ${ }^{124} \mathrm{Xe}$ may be present in these xenon fractions. It is important to add, however, that with a highly carbonaceous material such as thucholite the possibility of hydrocarbon contamination in the xenon region must certainly be considered. The 


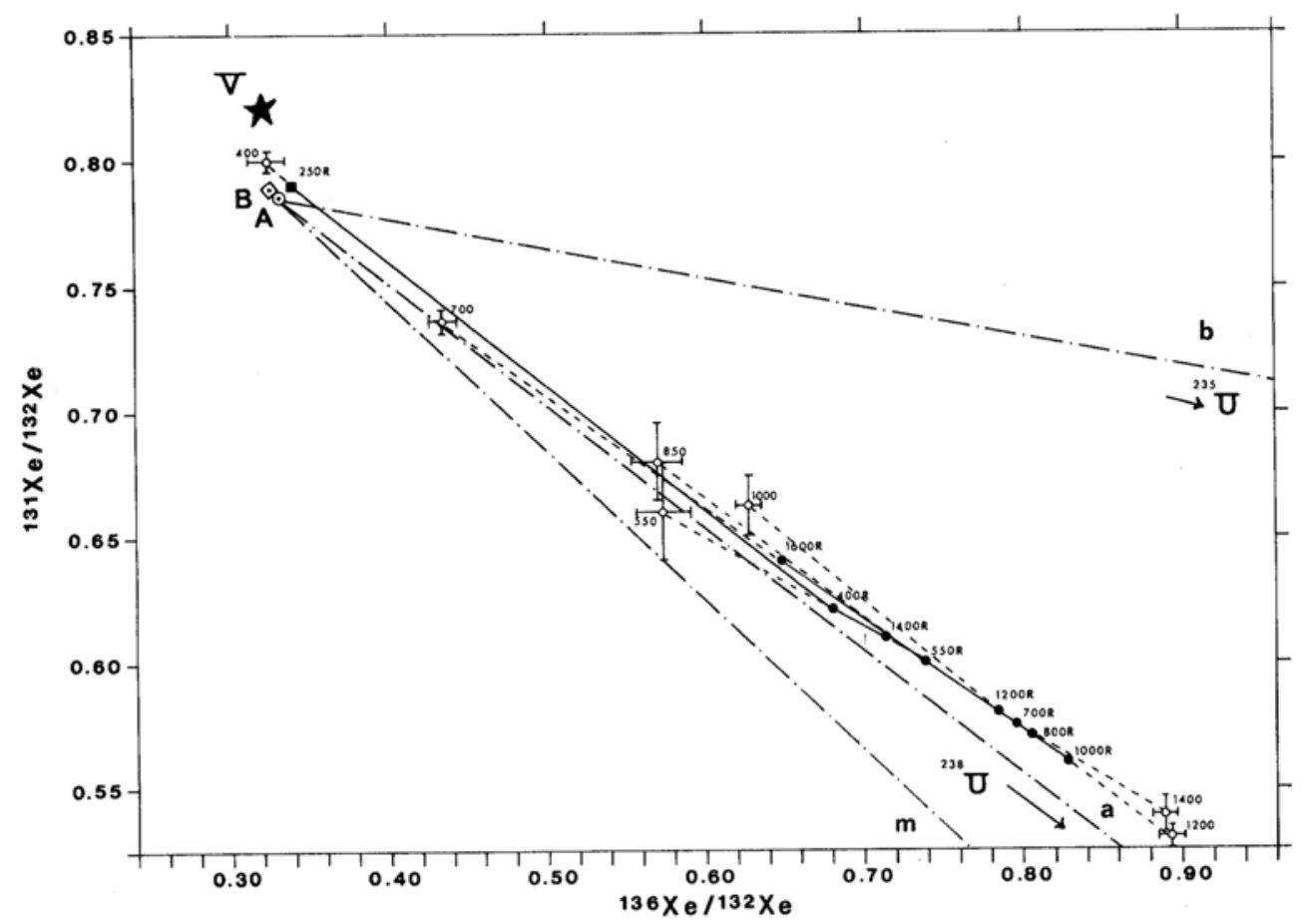

Fig. 2. Plot of ${ }^{131} \mathrm{Xe} /{ }^{132} \mathrm{Xe}$ vs. ${ }^{136} \mathrm{Xe} /{ }^{132} \mathrm{Xe}$ for the xenon fractions released from thucholite. Notation is the same as in Fig. 1.

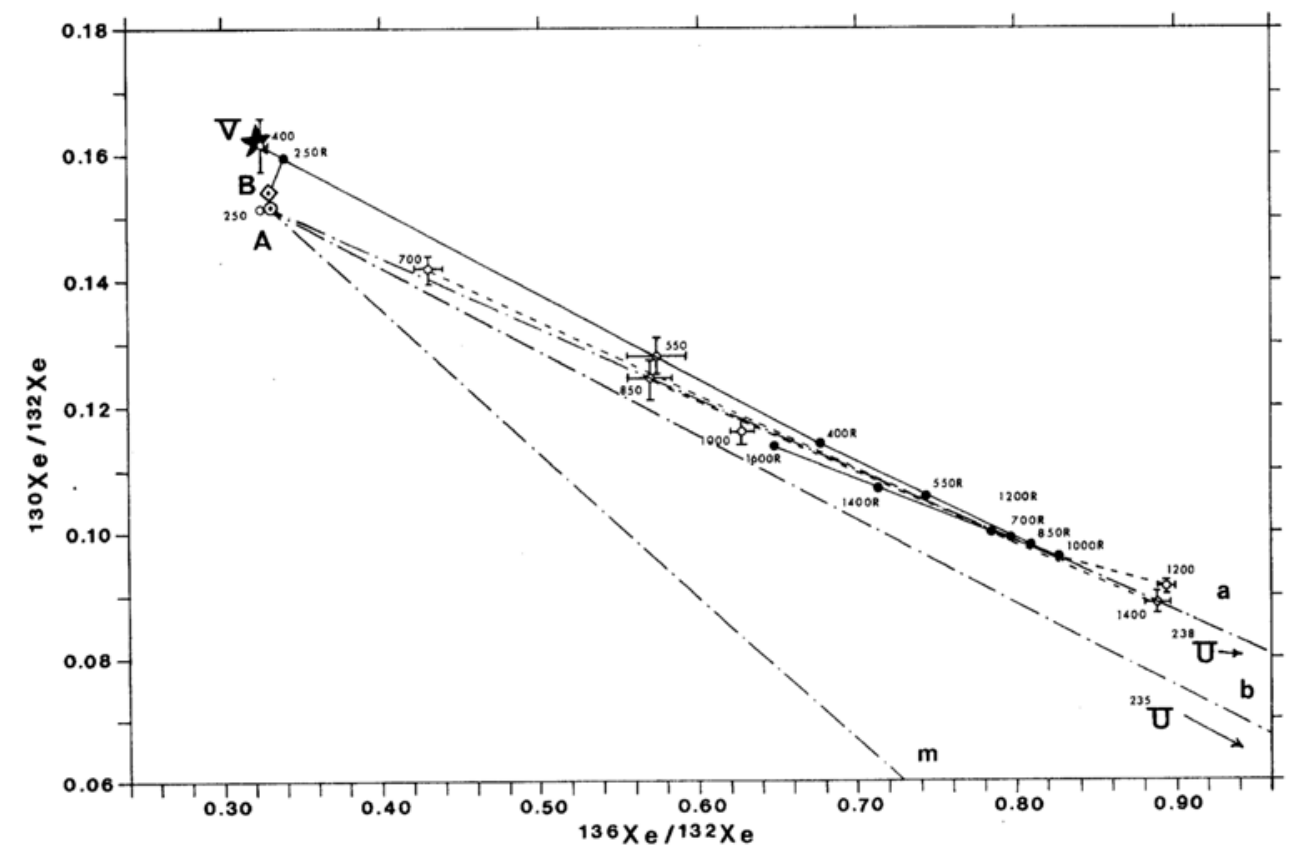

Fig. 3. Plot of ${ }^{130} \mathrm{Xe} /{ }^{132} \mathrm{Xe}$ vs. ${ }^{136} \mathrm{Xe} /{ }^{132} \mathrm{Xe}$ for the xenon fractions released from thucholite. Notation is the same as in Fig. 1. 


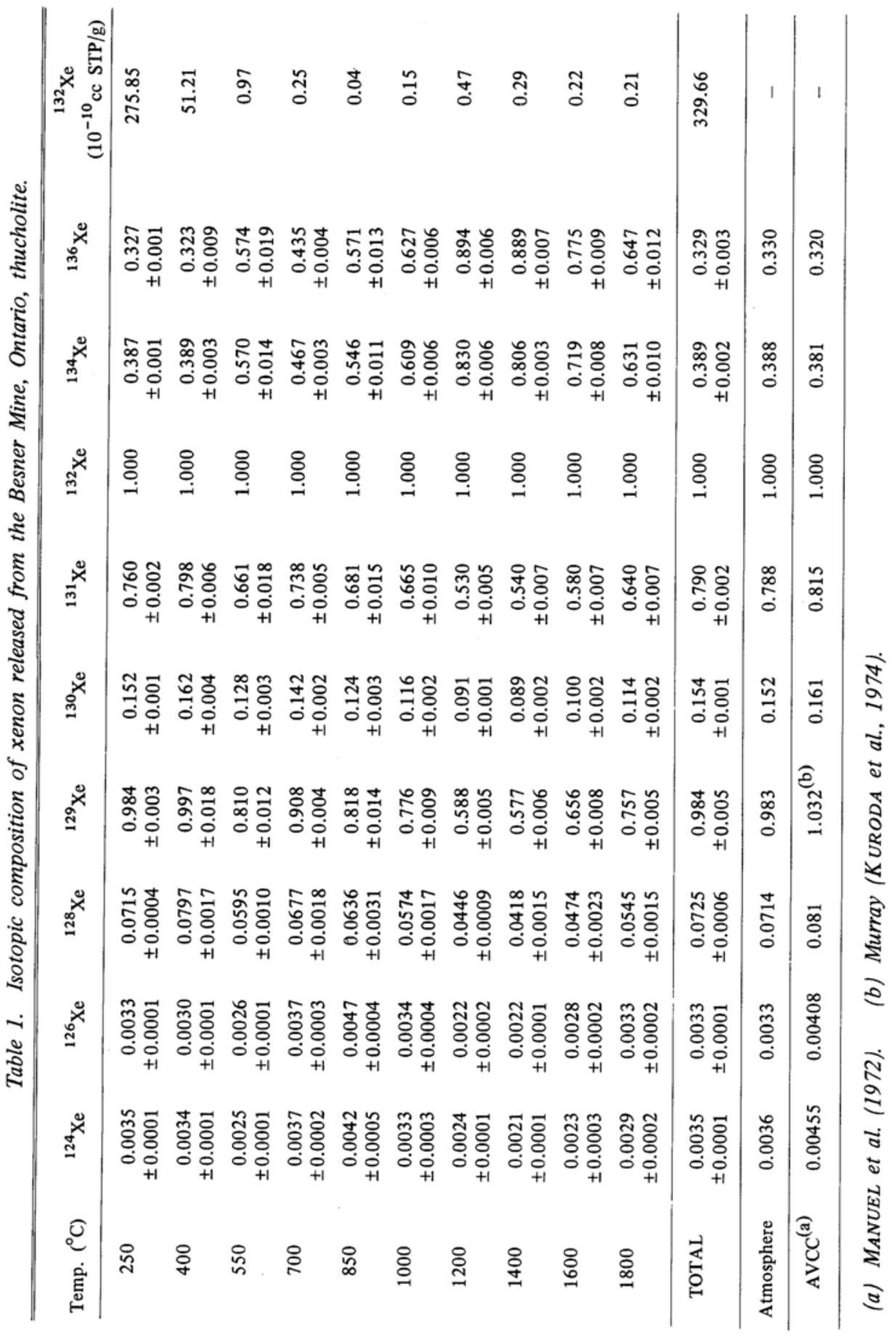




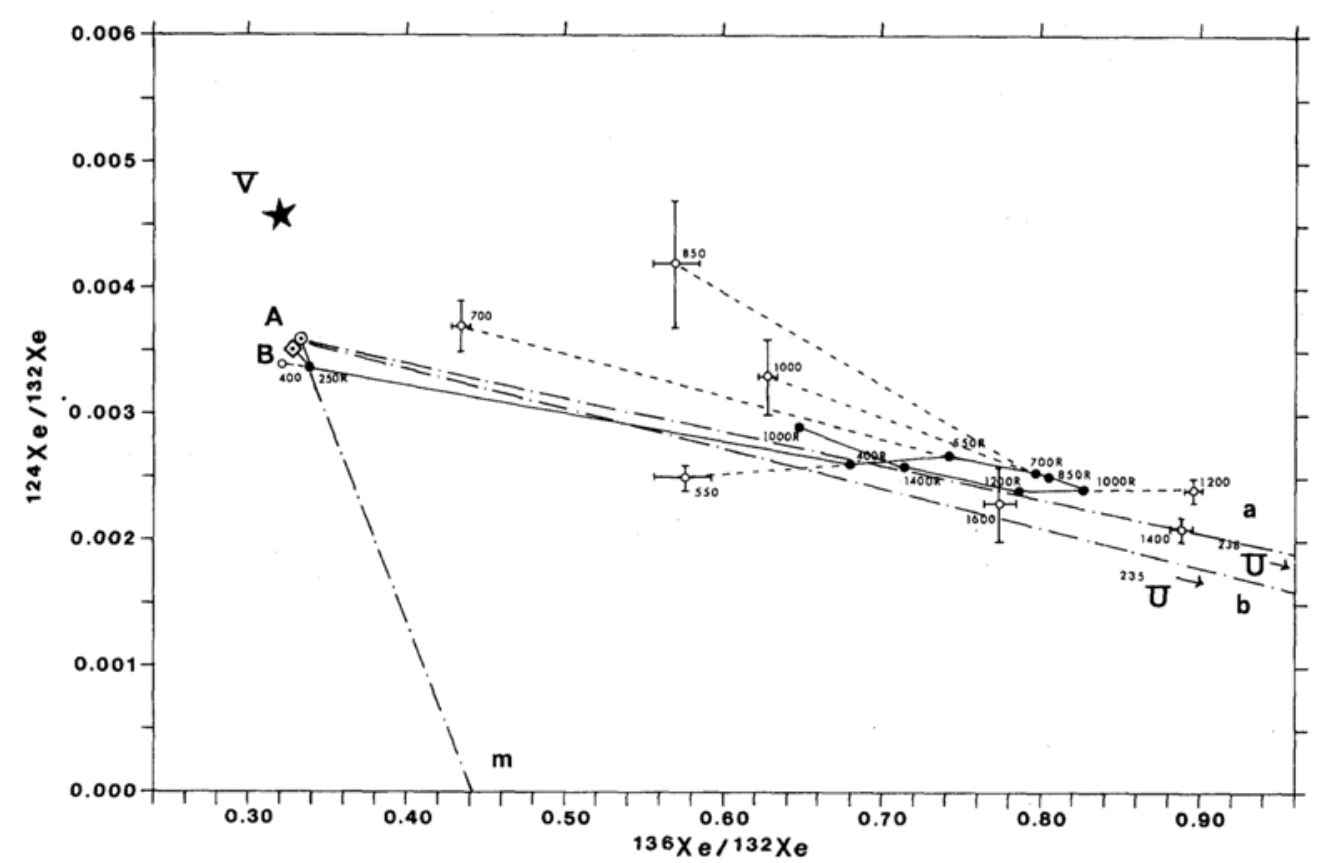

Fig. 4. Plot of ${ }^{124} \mathrm{Xe} /{ }^{132} \mathrm{Xe}$ vs. ${ }^{136} \mathrm{Xe} /{ }^{132} \mathrm{Xe}$ for the xenon fractions released from thucholite. Notation is the same as in Fig. 1.

amount of ${ }^{132} \mathrm{Xe}$ found in the $850^{\circ} \mathrm{C}$ fraction, for example, is only $4 \times 10^{-12} \mathrm{cc} \mathrm{STP} / \mathrm{g}$., and the amount of excess cosmic-ray-produced ${ }^{124} \mathrm{Xe}$ in the $850^{\circ} \mathrm{C}$ fraction corresponds to only $0.5 \mathrm{X}$ $10^{-14} \mathrm{cc} \mathrm{STP} / \mathrm{g}$. However, a plot of ${ }^{126} \mathrm{Xe} /{ }^{132} \mathrm{Xe}$ versus ${ }^{136} \mathrm{Xe} /{ }^{132} \mathrm{Xe}$ also reveals the presence of approximately $0.8 \times 10^{-14} \mathrm{cc} \mathrm{STP} / \mathrm{g}$ of excess ${ }^{126} \mathrm{Xe}$ in the $850^{\circ} \mathrm{C}$ fraction. The ratio of the excess ${ }^{124} \mathrm{Xe}$ and ${ }^{126} \mathrm{Xe}$ in the $850^{\circ} \mathrm{C}$ fraction is $0.5 / 0.8=0.63$ and is in agreement with the known cosmic-ray production ratio for ${ }^{124} \mathrm{Xe}$ and ${ }^{126} \mathrm{Xe}$ (CLARK et al., 1967).'

Figure 5 shows a plot of ${ }^{83} \mathrm{Kr} /{ }^{84} \mathrm{Kr}$ versus ${ }^{86} \mathrm{Kr} /{ }^{84} \mathrm{Kr}$. The krypton data are less accurate than the xenon data shown earlier, and it can not be decided from the data plotted in Fig. 5 whether the fissiogenic krypton isotopes in thucholite were produced by the spontaneous fission of ${ }^{238} \mathrm{U}$ or the neutron-induced fission of ${ }^{235} \mathrm{U}$. The data point for the $1,800^{\circ} \mathrm{C}$ fraction falls near the line $m A m^{\prime}$ representing the change of the isotopic composition $(A)$ of the atmospheric xenon by the process of massdependent fractionation.

Figure 6 shows a plot of ${ }^{82} \mathrm{Kr} /{ }^{84} \mathrm{Kr}$ versus ${ }^{86} \mathrm{Kr} /{ }^{84} \mathrm{Kr}$. The data points are scattered and many of them do not fall on the line $A a$. The scatter of the data points may be due to either (a) the effect of cosmic-ray irradiation, (b) the effect of mass-dependent fractionation or (c) hydrocarbon contamination. The ${ }^{80} \mathrm{Kr}$ data are not plotted here, but a plot of ${ }^{80} \mathrm{Kr} /{ }^{84} \mathrm{Kr}$ versus ${ }^{86} \mathrm{Kr} /{ }^{84} \mathrm{Kr}$ shows an even more pronounced trend that there exists an excess of ${ }^{80} \mathrm{Kr}$ in the krypton fractions released from thucholite. The peak heights at mass 80 may have been enhanced by the ${ }^{40} \mathrm{Ar}^{+}{ }_{2}$ peaks.

The amounts of fissiogenic xenon isotopes released from a mineral at different temperatures were calculated from the equations

$$
Q^{\mathrm{i}}=(1-\psi) \cdot P^{\mathrm{i}}+\psi \cdot F^{\mathrm{i}}
$$

and

$$
\left({ }^{\mathrm{i}} \mathrm{Xe}\right)_{\mathrm{f}}=\psi \cdot\left({ }^{132} \mathrm{Xe}\right)
$$

where $P^{\mathrm{i}}$ and $Q^{\mathrm{i}}$ are the ${ }^{\mathrm{i}} \mathrm{Xe} /{ }^{132} \mathrm{Xe}$ ratios in the atmospheric xenon and in the xenon fraction released from a mineral at a certain temperature, respectively; $F^{\mathrm{i}}$ is the ${ }^{\mathrm{i}} \mathrm{Xe} /{ }^{132} \mathrm{Xe}$ ratios corresponding to the known mass-yield distribution; $\psi$ is the fraction of the fissiogenic ${ }^{132} \mathrm{Xe}$ in the total ${ }^{132} \mathrm{Xe}$ found in the xenon fraction released from the sample; $\left({ }^{132} \mathrm{Xe}\right)$ is the amount of total ${ }^{132} \mathrm{Xe}$ found in the xenon fraction; and $\left({ }^{\mathrm{i}} \mathrm{Xe}\right)_{\mathrm{f}}$ is the amount of fissiogenic ${ }^{\mathrm{i}} \mathrm{Xe}$ found in the same xenon fraction. 
Table 2. Isotopic composition of krypton released from the Besner Mine, Ontario, thucholite.

\begin{tabular}{|c|c|c|c|c|c|c|}
\hline Temp. $\left({ }^{\circ} \mathrm{C}\right)$ & ${ }^{80} \mathrm{Kr}$ & ${ }^{82} \mathrm{~K}_{\mathrm{r}}$ & ${ }^{83} \mathrm{Kr}$ & ${ }^{84} \mathrm{Kr}$ & ${ }^{86} \mathrm{Kr}$ & $\begin{array}{c}{ }^{84} \mathrm{Kr} \\
\left(10^{-10} \mathrm{cc} \text { STP } / \mathrm{g}\right)\end{array}$ \\
\hline 250 & $\begin{array}{r}0.0390 \\
\pm 0.0006\end{array}$ & $\begin{array}{r}0.200 \\
\pm 0.001\end{array}$ & $\begin{array}{r}0.200 \\
\pm 0.001\end{array}$ & 1.000 & $\begin{array}{r}0.311 \\
\pm 0.001\end{array}$ & 20.99 \\
\hline 400 & 一 & $\begin{array}{r}0.209 \\
\pm 0.015\end{array}$ & $\begin{array}{r}0.210 \\
\pm 0.010\end{array}$ & 1.000 & $\begin{array}{r}0.353 \\
\pm 0.011\end{array}$ & 1.16 \\
\hline 550 & - & $\begin{array}{r}0.208 \\
\pm 0.003\end{array}$ & $\begin{array}{r}0.206 \\
\pm 0.010\end{array}$ & 1.000 & $\begin{array}{r}0.322 \\
\pm 0.007\end{array}$ & 0.65 \\
\hline 700 & $\begin{array}{r}0.0532 \\
\pm 0.0042\end{array}$ & $\begin{array}{r}0.211 \\
\pm 0.007\end{array}$ & $\begin{array}{r}0.204 \\
\pm 0.004\end{array}$ & 1.000 & $\begin{array}{r}0.320 \\
\pm 0.008\end{array}$ & 0.25 \\
\hline 850 & $\begin{array}{r}0.0556 \\
\pm 0.0019\end{array}$ & $\begin{array}{r}0.214 \\
\pm 0.016\end{array}$ & $\begin{array}{r}0.206 \\
\pm 0.011\end{array}$ & 1.000 & $\begin{array}{r}0.334 \\
\pm 0.015\end{array}$ & 0.07 \\
\hline 1000 & $\begin{array}{r}0.0476 \\
\pm 0.0026\end{array}$ & $\begin{array}{r}0.208 \\
\pm 0.008\end{array}$ & $\begin{array}{r}0.201 \\
\pm 0.006\end{array}$ & 1.000 & $\begin{array}{r}0.420 \\
\pm 0.008\end{array}$ & 0.18 \\
\hline 1200 & $\begin{array}{r}0.0430 \\
\pm 0.0026\end{array}$ & $\begin{array}{r}0.199 \\
\pm 0.003\end{array}$ & $\begin{array}{r}0.204 \\
\pm 0.002\end{array}$ & 1.000 & $\begin{array}{r}0.471 \\
\pm 0.011\end{array}$ & 0.69 \\
\hline 1400 & $\begin{array}{r}0.0508 \\
\pm 0.0021\end{array}$ & $\begin{array}{r}0.205 \\
\pm 0.003\end{array}$ & $\begin{array}{r}0.201 \\
\pm 0.004\end{array}$ & 1.000 & $\begin{array}{r}0.342 \\
\pm 0.007\end{array}$ & 0.56 \\
\hline 1600 & $\begin{array}{r}0.0499 \\
\pm 0.0030\end{array}$ & $\begin{array}{r}0.206 \\
\pm 0.005\end{array}$ & $\begin{array}{r}0.201 \\
\pm 0.004\end{array}$ & 1.000 & $\begin{array}{r}0.314 \\
\pm 0.004\end{array}$ & 0.82 \\
\hline 1800 & - & $\begin{array}{r}0.217 \\
\pm 0.002 \\
\end{array}$ & $\begin{array}{r}0.208 \\
\pm 0.002 \\
\end{array}$ & 1.000 & $\begin{array}{r}0.295 \\
\pm 0.003 \\
\end{array}$ & 1.82 \\
\hline TOTAL & - & $\begin{array}{r}0.202 \\
\pm 0.002 \\
\end{array}$ & $\begin{array}{r}0.201 \\
\pm 0.002 \\
\end{array}$ & 1.000 & $\begin{array}{r}0.317 \\
\pm 0.003 \\
\end{array}$ & 27.17 \\
\hline Atmosphere & 0.0396 & 0.202 & 0.202 & 1.000 & 0.306 & 一 \\
\hline $\operatorname{AVCC}^{(a)}$ & 0.0394 & 0.199 & 0.200 & 1.000 & 0.309 & - \\
\hline
\end{tabular}

(a) EUGSTER et al. (1967).

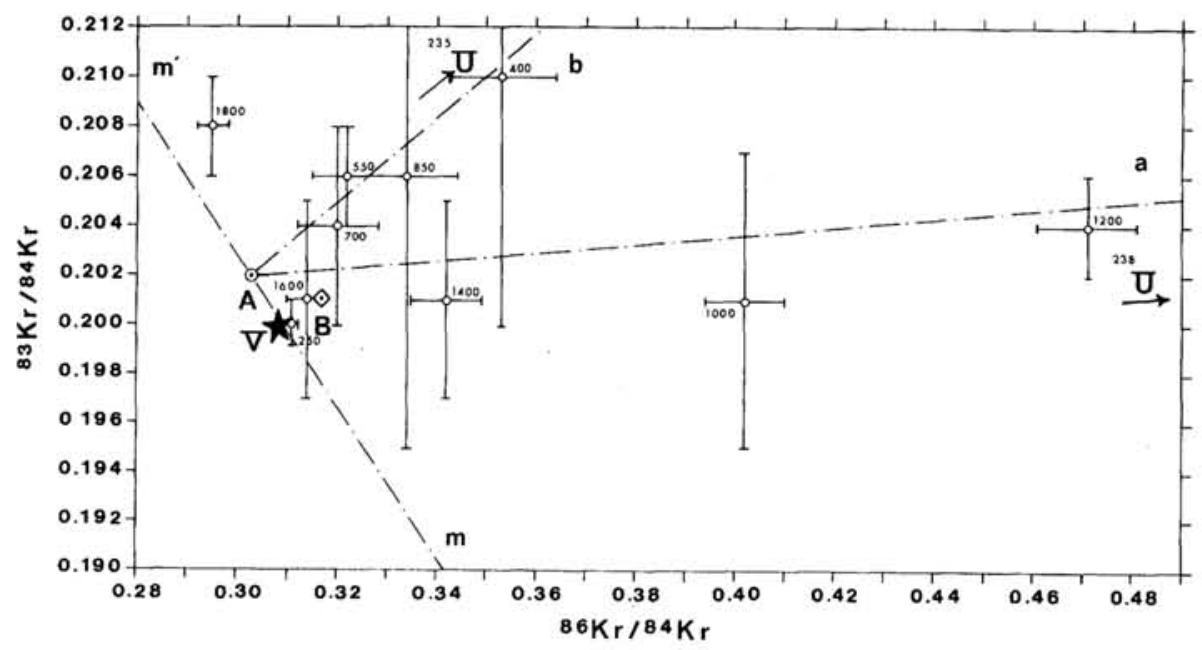

Fig. 5. Plot of ${ }^{83} \mathrm{Kr} /{ }^{84} \mathrm{Kr}$ vs. ${ }^{86} \mathrm{Kr} /{ }^{84} \mathrm{Kr}$ for the krypton fractions released from thucholite. Notation is the same as in the cases of xenon, shown in Figs. 1-4. 


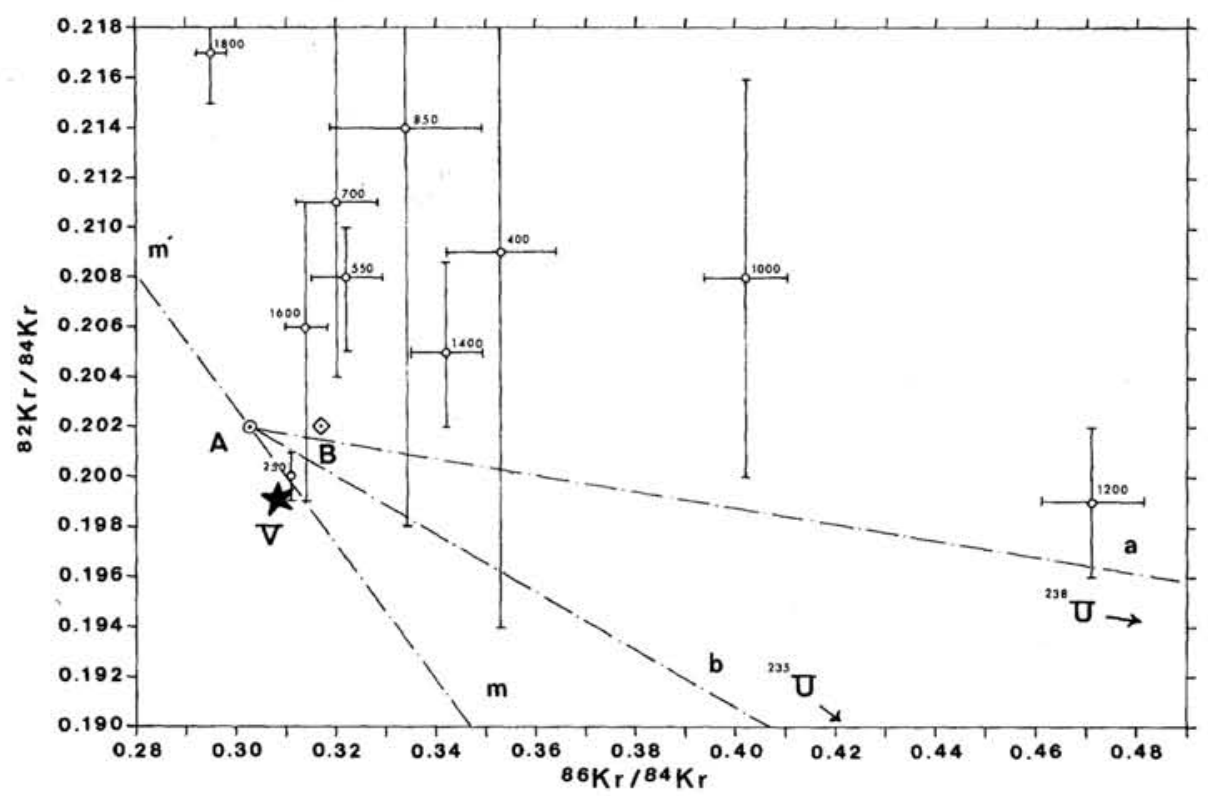

Fig. 6. Plot of ${ }^{82} \mathrm{Kr} /{ }^{84} \mathrm{Kr}$ vs. ${ }^{86} \mathrm{Kr} /{ }^{84} \mathrm{Kr}$ for the krypton fractions released from thucholite. Notation is the same as in Fig. 5.

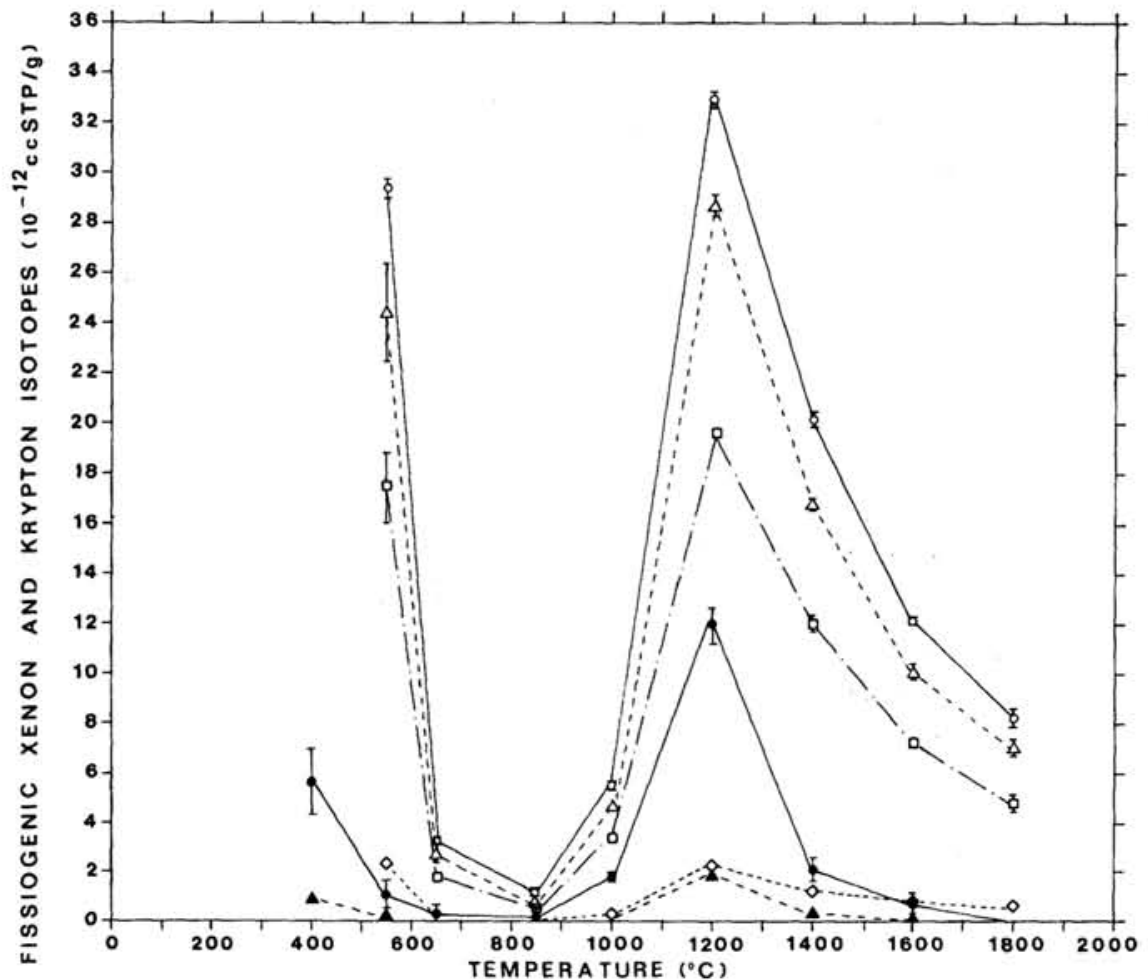

Fig. 7. Release patterns of the fissiogenic xenon and krypton isotopes from thucholite.

$$
\begin{array}{ll}
\circ: & \\
\Delta:{ }^{136 f} \mathrm{Xe} \\
{ }^{134 f} \mathrm{Xe} \\
\square:{ }^{132 f} \mathrm{Xe} & \\
\diamond:{ }^{131 f} \mathrm{Xe} & \bullet:{ }^{86 f_{K r}}
\end{array}
$$


The amounts of fissiogenic krypton isotopes released from the thucholite were calculated from the observed values of ${ }^{i} \mathrm{Kr} /{ }^{84} \mathrm{Kr}$ in a similar manner, and the results are plotted in Fig. 7.

Figure 7 shows that, while a peak release of the fissiogenic rare gases occurs at $1,200^{\circ} \mathrm{C}$, far greater amounts of the fissiogenic gases may have escaped at temperatures lower than $600^{\circ} \mathrm{C}$. We have calculated the relative amounts of the fissiogenic xenon and krypton isotopes released in the temperature range between 550 and $1,800^{\circ} \mathrm{C}$ from the data shown in Fig. 7. These results are expressed in the form of fission yields relative to an assumed value of 6.00 percent for ${ }^{136} \mathrm{Xe}$, and are shown in Table 3.

Figure 8 shows a fission mass-yield curve constructed from the total amounts of the fissiogenic rare gases released from the thucholite in the temperature range $550-1,800^{\circ} \mathrm{C}$. The mirror points were calculated by assuming the average number of neutrons emitted per fission to be 2 . The mass-yield curve thus obtained is in reasonably good agreement with that for the spontaneous fission of ${ }^{238} \mathrm{U}$ (WeTHerill, 1953; Hyde, 1964). Table 3 shows, however, that while the relative amounts of the four fissiogenic xenon isotopes remain fairly constant throughout the temperature range, the ratio of the fissiogenic krypton isotopes to the fissiogenic xenon isotopes vary significantly with release temperature. Thus, the krypton isotopes appear to be preferentially released over the xenon isotopes at temperatures 1,000 and $1,200^{\circ} \mathrm{C}$.

The amount of ${ }^{136} \mathrm{Xe}$ which is produced by the spontaneous fission of ${ }^{238} \mathrm{U}$ in a mineral whose age is $t$ years is given by

$$
\left({ }^{136 f} \mathrm{Xe}\right)=\left({ }^{238} \mathrm{U}\right)\left(\mathrm{e}^{\lambda_{\alpha} t}-1\right) \cdot \frac{\lambda_{\mathrm{f}}}{\lambda_{\alpha}+\lambda_{\mathrm{f}}} \cdot y
$$

where $\left({ }^{136 f} \mathrm{Xe}\right)$ and $\left({ }^{238} \mathrm{U}\right)$ are the number of atoms of fissiogenic ${ }^{136} \mathrm{Xe}$ and ${ }^{238} \mathrm{U}$ found in the mineral today, respectively; $\lambda_{\alpha}$ and $\lambda_{\mathrm{f}}$ are the alpha and spontaneous fission decay constants of ${ }^{238} \mathrm{U}$, respectively; and $y$ is the spontaneous fission yield at mass number 136 .

The uranium content of a portion of the thucholite sample used in this study has been determined to be 4.98 percent by the activation analysis method. According to MUENCH (1937), a typical thucholite from this locality had the following chemical composition: $4.63 \% \mathrm{U}$, $0.903 \% \mathrm{Th}, 0.186 \% \mathrm{~Pb}, 4.53 \%$ silica and $21.52 \%$ ash. From these data, he obtained a value of 278 million years for the approximate uranium-lead age of the thucholite. NIER et al. (1941) found the ${ }^{206} \mathrm{~Pb} /{ }^{238} \mathrm{U},{ }^{208} \mathrm{~Pb} /{ }^{232} \mathrm{Th}$ and ${ }^{207} \mathrm{~Pb} /{ }^{206} \mathrm{~Pb}$ ages of a sample of Parry Sound thucholite to be 265, 245 and $430 \pm 40$ million years, respectively. The ages thus obtained for thucholite are all much younger than the age of about 1,000 million years for a sample of pitchblende from Parry Sound. These results suggest that the thucholite samples were subjected to appreciable alterations during the geological history. If it is assumed that $y=$ 6 (percent), equation (3) yields a value of ${ }^{136 \mathrm{f}} \mathrm{Xe}=0.6 \times 10^{-8} \mathrm{cc} \mathrm{STP} / \mathrm{g}$ for $t=250$ million years and ${ }^{136 f} \mathrm{Xe}=1.07 \times 10^{-8} \mathrm{cc} \mathrm{STP} / \mathrm{g}$ for $t=$

Table 3. Relative abundances of the fissiogenic xenon and krypton isotopes released from the Besner Mine, Ontario, thucholite at various temperatures. These values are expressed in terms of an assumed fission yield of 6.00 percent fo ${ }^{136} \mathrm{Xe}$.

\begin{tabular}{|c|c|c|c|c|c|c|c|}
\hline Temp. $\left({ }^{\circ} \mathrm{C}\right)$ & ${ }^{83 f_{K r}}$ & ${ }^{84 f} \mathrm{Kr}$ & ${ }^{86 f} \mathrm{Kr}_{\mathrm{r}}$ & ${ }^{131 f} \mathrm{Xe}$ & ${ }^{132 f} \mathrm{Xe}$ & ${ }^{134 f} \mathrm{Xe}$ & ${ }^{136 f} \mathrm{Xe}$ \\
\hline 250 & - & - & - & - & - & - & - \\
\hline 400 & - & - & - & - & - & - & - \\
\hline 550 & $(0.16 \pm 0.04)$ & $0.037 \pm 0.014$ & $0.23 \pm 0.09$ & $0.47 \pm 0.04$ & $2.96 \pm 0.28$ & $4.99 \pm 0.40$ & 6.00 \\
\hline 700 & $(0.4 \pm 0.6)$ & $0.11 \pm 0.06$ & $0.68 \pm 0.39$ & $0.44 \pm 0.04$ & $3.57 \pm 0.15$ & $5.02 \pm 0.18$ & 6.00 \\
\hline 850 & $(0.5 \pm 1.0)$ & $0.15 \pm 0.10$ & $1.06 \pm 0.55$ & $0.40 \pm 0.05$ & $3.58 \pm 0.20$ & $4.39 \pm 0.30$ & 6.00 \\
\hline 1000 & $(0.1 \pm 0.3)$ & $0.31 \pm 0.02$ & $1.97 \pm 0.12$ & $0.37 \pm 0.03$ & $3.57 \pm 0.06$ & $4.97 \pm 0.13$ & 6.00 \\
\hline 1200 & $(0.07 \pm 0.07)$ & $0.35 \pm 0.02$ & $2.17 \pm 0.14$ & $0.41 \pm 0.01$ & $3.57 \pm 0.03$ & $5.22 \pm 0.06$ & 6.00 \\
\hline 1400 & $(0.06 \pm 0.21)$ & $0.10 \pm 0.02$ & $0.63 \pm 0.12$ & $0.40 \pm 0.01$ & $3.57 \pm 0.04$ & $4.99 \pm 0.04$ & 6.00 \\
\hline 1600 & $(0.1 \pm 0.5)$ & $0.054 \pm 0.030$ & $0.34 \pm 0.19$ & $0.42 \pm 0.01$ & $3.57 \pm 0.07$ & $4.96 \pm 0.12$ & 6.00 \\
\hline 1800 & - & - & - & $0.42 \pm 0.02$ & $3.57 \pm 0.14$ & $5.11 \pm 0.21$ & 6.00 \\
\hline TOTAL & $(0.11 \pm 0.16)$ & $0.154 \pm 0.021$ & $0.97 \pm 0.12$ & $0.43 \pm 0.02$ & $3.57 \pm 0.12$ & $5.06 \pm 0.16$ & 6.00 \\
\hline $\begin{array}{l}\text { rom }{ }^{238} \mathrm{U} \text { spon- } \\
\text { aneous fission (a) }\end{array}$ & $036 \pm 0$ & $0.119 \pm 0.040$ & $0.75 \pm 0.11$ & $0.455 \pm 0.02$ & $3.57 \pm 0.06$ & $4.99 \pm 0.17$ & 6.00 \\
\hline
\end{tabular}

(a) WETHERILL (1953). 


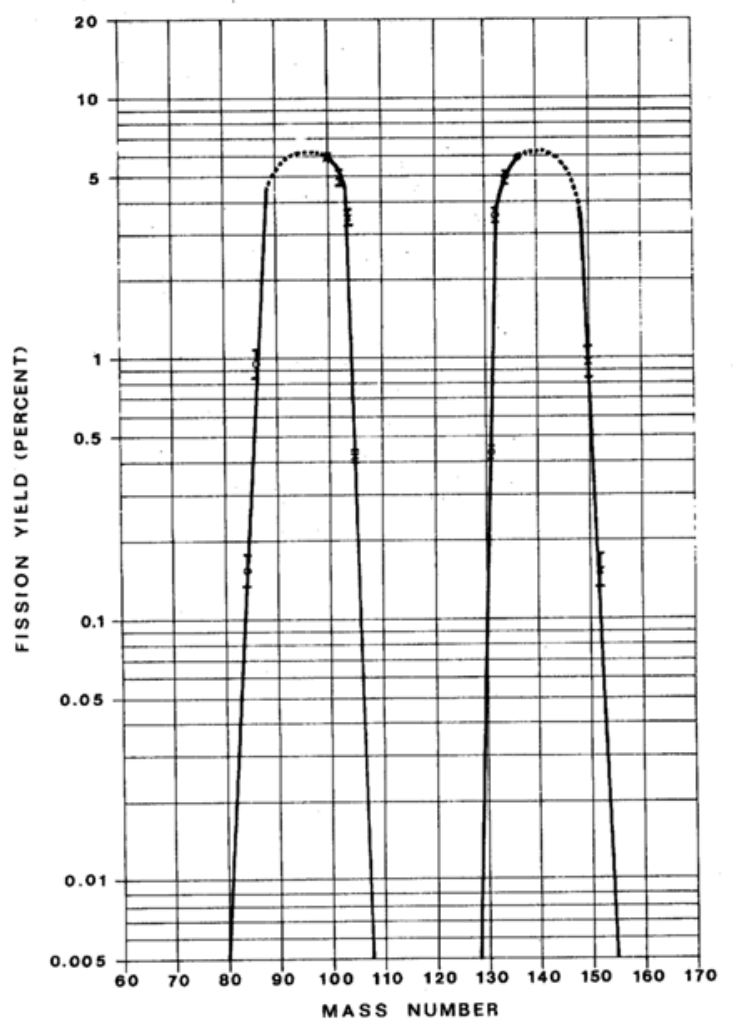

Fig. 8. Mass-yield curve for the fissiogenic xenon and krypton isotopes released from thucholite in the temperature range $550-1,800^{\circ} \mathrm{C}$. The mirror points were calculated by assuming the average number of neutrons emitted per fission to be 2 .

430 million years. These values are 60 to 100 times the value of $1.13 \times 10^{-10} \mathrm{cc} \mathrm{STP} \mathrm{of}{ }^{136 f} \mathrm{Xe} /$ $\mathrm{g}$ actually found in the thucholite. It thus appears as if most of the fissiogenic xenon isotopes were lost during the lifetime of the mineral.

As it has been mentioned earlier, extremely small quantities of cosmic-ray-produced ${ }^{124} \mathrm{Xe}$ and ${ }^{126} \mathrm{Xe}$ appear to be present in the thucholite. The total amount of cosmic-ray-produced ${ }^{126} \mathrm{Xe}$ released from the mineral in the temperature range between $700^{\circ} \mathrm{C}$ and $1,200^{\circ} \mathrm{C}$, for example, can be calculated to be $(3.7 \pm 1.7) \times 10^{-14} \mathrm{cc}$ $\mathrm{STP} / \mathrm{g}$. This is roughly equal to the amounts of cosmic-ray-produced ${ }^{126} \mathrm{Xe}$ found in barites. SRINIVASAN (1976) has recently reported the amounts of cosmic-ray-produced ${ }^{126} \mathrm{Xe}$ in 3 billion year-old samples of Swaziland and Australian barites to be $5 \times 10^{-14}$ and 2.2 to $3.3 \times$ $10^{-14} \mathrm{cc} \mathrm{STP} / \mathrm{g}$, respectively. Considering the facts that (a) the barites are much older than the thucholite and (b) the barium content of the barites is much greater than that of the thucholite, it seems that there is much too great an excess of ${ }^{126} \mathrm{Xe}$ in the thucholite.

It is interesting to speculate on the possibility that the occurrence of a meteoritic rare gas component in thucholite may have some bearings on the process of meteorite impact. According to McKeAN (1964), a meteoritic crater exists in the Pre-Cambrian shield in the Parry Sound district, Ontario, Canada (see also, FreEberG, 1966). According to French (1970), sufficiently large meteorite impacts should have occurred in the past 2 billion years to produce, on the present land areas of the earth, approximately 100,000 craters larger than Meteor Crater, Arizona, approximately 6,000 larger than $5 \mathrm{~km}$ in diameter, and about 20 the size of the Sudbury structure, Ontario, Canada, with a diameter of $50 \mathrm{~km}$ (see also, F RENCH, 1967, 1972). When the effects of crater removal by erosion, burial, or orogeny are considered, astronomical and geological data both seem to support the present existence of perhaps several hundred large impact craters on the land areas of the earth.

A complete fusion, injection, and rapid crystallization of large volumes of target rocks may have occurred during the impact event. Such an event may have been accompanied by the release of fissiogenic xenon isotopes from the rocks and minerals and also the introduction of significant quantities of rare gases from an extraterrestrial source into the terrestrial rocks and minerals. Gas-rich carbonaceous materials, such as thucholite, may have absorbed part of the rare gases from an extraterrestrial origin, which also contained appreciable quantities of cosmic-ray-produced rare gases. Further studies along these lines are obviously needed in order to be able to fully explain the xenon and krypton isotope anomalies observed in thucholite.

Acknowledgments-This investigation was supported by the National Science Foundation under Grant NSF EAR 76-00285. We are grateful to Dr. J. N. BECK for his advice; to Mr. RICHARD DOUGHERTY for his expert glassblowing; to Mr. KENNETH MCELVEEN for his assistance in electronics. One of us (R.D.S.) is grateful to the Phillips Petroleum Company for granting a graduate fellowship during his last year of study. 


\section{REFERENCES}

Bogard, D. D., Rowe, M. W., Manuel, O. K., and KURODA, P. K. (1965) Noble gas anomalies in the mineral thucholite. J. Geophys. Res. 70, 703-708.

Clark, R. S., RAO, M. N., and KURODA, P. K.(1967) Fission and spallation xenon in meteorites. ibid. 72, 5143-5148.

Eugster, O., EberhardT, P., and Geiss, J. (1967) Krypton and xenon isotopic composition in three carbonaceous chondrites. Earth Planet. Sci. Lett. 3, 249-257.

FREEBERG, J. H. (1966) Terrestrial impact structures a bibliography. U.S. Geol. Survey Bull. 1220, 1-91.

FRENCH, B. M. (1967) Sudbury structure, Ontario: Some petrographic evidence for origin by meteorite impact. Science 156, 1094-1098.

FrENCH, B. M. (1970) Possible relations between meteorite impact and igneous petrogenesis, as indicated by the Sudbury structure, Ontario, Canada. Bull. Volcanologique XXXIV-2, 466-517.

FRENCH, B. M. (1972) Shock-metamorphic features in the Sudbury structure, Ontario. The Geological Association of Canada, Special Paper Number 10, 19-28.

HydE, E. K. (1964) The nuclear properties of the heavy elements, III. Fission phenomena. PrenticeHall, Inc., Englewood Cliff, New Hersey, p. 124.

KURODA, P. K. (1956a) On the nuclear physical stability of the uranium minerals. J. Chem. Phys. 25, 781-782.

KURODA, P. K. (1956b) On the infinite multiplication constant and the age of the uranium minerals. ibid. 25, 1295-1296.

KURODA, P. K. (1975) Fossil nuclear reactor and plutonium-244 in the early history of the solar system. The Oklo Phenomenon, Proceedings of a symposium, Libreville, 23-27 June 1975, IAEA, Vienna, 1975, 479-487.
Kuroda, P. K., BECK, J. N., EFurd, D. W. and MiLLER, D. K. (1974) Xenon isotope anomalies in the carbonaceous chondrite Murray. J. Geophys. Res. 79, 3981-3992.

KURODA, P. K., Sherrill, R. D., EFURD, D. W. and BECK, J. N. (1975) Xenon isotope anomalies in the carbonaceous chondrite Murchison. ibid. 80, 15581570.

Manuel, O. K., Wright, R. J., MilleR, D. K. and KURODA, P. K. (1972) Isotopic compositions of rare gases in the carbonaceous chondrites Mokoia and Allende. Geochim. Cosmochim. Acta 36, 961983.

McKean, F. K. (1964) A meteoritic crater in the PreCambrian shield. Meteoritics 2, 243-248.

MUENCH, O. B. (1937) The determination of uranium, thorium, and lead in thucholite. J. Am. Chem. Soc. 59, 2269-2270.

Neuilly, M., Bussac, J., FréJaceues, C., Nief, G., VENDRYES, G., and YVON, J. (1972) Sur l'existence dans un passé recule d'une réaction en chaîne naturelle de fissions, dans le gisement d'uranium d'Oklo (Gabon). C. R. Acad. Sc. Paris 275, 18471849.

NiER, A. O., ThOMPSON, R. W., and MurPheY, B. F. (1941) The isotopic constitution of lead and the measurement of geological time. III. Phys. Rev. 60, $112-116$.

ORR, J. B. (1949) Uranium-235 in thucholite, ibid. 76, $155-155$.

ORR, J. B. (1950) Uranium-235 in thucholite. ibid. 79, 401-402.

SRINIVASAN, B. (1976) Barites: Anomalous xenon from spallation and neutron-induced reactions. Earth Planet. Sci. Lett. 31, 129-141.

WETHERILL, G. W. (1953) Spontaneous fission yields from uranium and thorium. Phys. Rev. 92, 907912. 